John C. Poirier

\title{
The Tongues of Angels
}

\section{The Concept of Angelic Languages in Classical Jewish and Christian Texts}

[Die Engelszungen. Das Konzept der Engelssprachen in antiken jüdischen und christlichen Texten.]

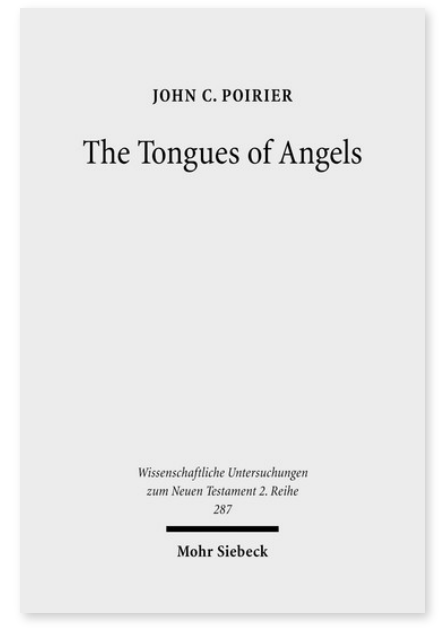

2010. XI, 224 Seiten. WUNT II 287

ISBN 978-3-16-151630-6

DOI 10.1628/978-3-16-151630-6

eBook PDF $74,00 €$

ISBN 978-3-16-150569-0

fadengeheftete Broschur $74,00 €$
Veröffentlicht auf Englisch.

Der Bezug des Apostels Paulus auf die »Engelszungen« (1. Kor. 13,1) hat schon immer eine gewisse Neugier geweckt, selten war er jedoch Gegenstand einer traditionsgeschichtlichen Untersuchung. Wenige Leser von Paulus' Texten sind sich der vielfältigen Bezugnahmen und Anspielungen zu Engelssprachen in jüdischen und christlichen Texten bewußt. John C. Poirier untersucht das Konzept der Engelssprachen erstmals ausführlich und versucht eingehend, Belege für dieses Konzept in antiken jüdischen und frühchristlichen Texten zusammenzutragen. Dazu erörtert er mögliche Anspielungen auf Engelssprachen im Neuen Testament, in sowohl jüdischen als auch christlichen pseudepigraphischen Schriften, in den Schriftenrollen vom Toten Meer, rabbinischen Texten, patristischen Bezügen, magischen Schriften und in der Epigraphik. Dabei wird unterschieden zwischen denjenigen, die davon ausgehen, daß die Engel Hebräisch sprechen, und denjenigen, die meinen, daß Engel eine esoterische oder himmlische Sprache sprechen.

John C. Poirier Born 1963; 1993 ThM in New Testament at Duke University; 2005 Doctor of Hebrew Letters in Ancient Judaism at the Jewish Theological Seminary (NY); named Chair of Biblical Studies at the newly forming Kingswell Theological Seminary $(\mathrm{OH})$.

\section{Jetzt bestellen:}

https://mohrsiebeck.com/buch/the-tongues-of-angels-9783161516306?no_cache=1

order@mohrsiebeck.com

Telefon: +49 (0)7071-923-17

Telefax: $+49(0) 7071-51104$ 